"They all seem to have inherited the horrible ugliness and sewer filth of sex": Catholic Guilt in Selected Works by John McGahern (1934-2006)

\title{
Eamon Maher
}

\section{(2) OpenEdition \\ 1 Journals}

\section{Electronic version}

URL: http://journals.openedition.org/etudesirlandaises/3959

DOI: 10.4000/etudesirlandaises.3959

ISSN: 2259-8863

\section{Publisher}

Presses universitaires de Rennes

\section{Printed version}

Date of publication: 20 November 2014

Number of pages: 101-113

ISBN: 978-2-7535-3559-6

ISSN: 0183-973X

Electronic reference

Eamon Maher, " "They all seem to have inherited the horrible ugliness and sewer filth of sex": Catholic Guilt in Selected Works by John McGahern (1934-2006) ", Études irlandaises [Online], 39-2 | 2014, Online since 20 November 2016, connection on 21 April 2019. URL : http://journals.openedition.org/ etudesirlandaises/3959; DOI : 10.4000/etudesirlandaises.3959 


\title{
"They all seem to have inherited the horrible ugliness and sewer filth of sex": Catholic Guilt in Selected Works by John McGahern (1934-2006)
}

\author{
Eamon MAHER \\ ITT Dublin
}

\begin{abstract}
John McGahern's literary canvas concentrates mainly on the north-western midlands of Ireland during the middle and latter half of the last century. Many of his characters, influenced by a rather puritanical brand of Catholicism, tend to view sexuality in a negative light and to see the body, especially the female body, as a source of sin. This article will discuss Catholic guilt in McGahern's unpublished first novel, "The End or the Beginning of Love", and the controversial second novel, The Dark, which was banned shortly after its publication in 1965, and show how accurately the mores and customs of Irish society of the time are reflected in these works.
\end{abstract}

Keywords: Pierre Bourdieu, censorship, Catholic guilt, John McGahern, sexuality, sin, Tom Inglis, Val Nolan.

\section{Résumé}

L'espace littéraire de John McGahern se situe principalement au nord-ouest des plaines centrales de l'Irlande des années 50 à la fin du XX siècle. Beaucoup de ses personnages, influencés par une variété plutôt puritaine du catholicisme, ont tendance à envisager la sexualité d'une manière négative et à considérer le corps, particulièrement celui de la fermme, comme la source du péché. Cet article se fixe pour objectif de discuter la culpabilité catholique telle qu'elle est représentée dans le premier roman inédit de McGahern, "The End or the Beginning of Love", et dans son deuxième roman polémique, The Dark, qui fut interdit peu de temps après sa publication en 1965. Nous verrons comment les moeurs et coutumes de la société irlandaise de l'époque se reflètent dans ces cuvres.

Mots clés: Pierre Bourdieu, censure, culpabilité catholique, John McGahern, sexualité, péché, Tom Inglis

1. This is a quote from the unpublished first novel, "The End or the Beginning of Love", for which there are various versions in the McGahern Archive at the Hardiman Library in NUI Galway. The one from which I quote is catalogued at P71/8. All subsequent references will be from this text, with page numbers is brackets. The quote above is on page 293. 
The Leitrim writer John McGahern is rightly acclaimed for his harsh, realistic depiction of rural Ireland in the 1940s, 50s and 60s, decades during which most of his best-known fiction is situated. Sexuality is rarely presented in a positive manner and much of his early writing, to which we will largely confine our attention in this article, is characterised by an unflinching exposure of a hidden Ireland characterised by psychological and sexual abuse, an unhealthy preoccupation with sins of the flesh, a guilt-ridden and overly pious population and a manipulative Catholic clergy. In Memoir, we encounter the following description of his childhood perception of Irish society:

Authority's writ ran from God the father down and could not be questioned. Violence reigned as often as not in the homes as well. One of the compounds at its base was sexual sickness and frustration, as sex was seen, officially, as unclean and sinful, allowable only when it too was licensed. Doctrine separated body and soul2 .

The writer had marked issues with what he perceived to be a puritanical, oppressive, patriarchal and authoritarian Church that intervened excessively in the sexual lives of Irish people. In an interview he did with me in November 2000, McGahern underlined his resentment of the way in which the Catholic Church insisted on linking sex with sin, an approach that inflicted severe psychological scars:

I would think that if there was one thing injurious about the Church, it would be its attitude to sexuality. I see sexuality as just part of life. Either all of life is sacred or none of it is sacred [...] And I think it (the Church) made a difficult enough relationship - which is between people, between men and women - even more difficult by imparting an unhealthy attitude to sexuality ${ }^{3}$.

It is noticeable that he does not include same-sex relationships in this comment; undoubtedly they would have been even more problematic, in some ways inconceivable, for practising Catholics at that time in Ireland. McGahern returned again and again to the dichotomy between what he considered to be a normal, healthy activity, namely sexual concourse between consenting adults, and the taboo that was attached to it by Irish Catholicism. The sociologist Tom Inglis, in his groundbreaking study, Moral Monopoly, first published in 1987, borrowing on the work of the French sociologist Pierre Bourdieu, describes the social capital that was attached to being perceived to be a good Catholic in Ireland. In Inglis'

2. John McGahern, Memoir, London, Faber \& Faber, 2005, p. 18.

3. "Catholicism and National Identity in the Works of John McGahern". Interview between Eamon Maher and John McGahern, Studies: An Irish Quarterly, Vol 90, no 357, Spring 2001, p. 73-74. 
opinion, it was easier for good Catholics to advance in political life, the professions, within the local community and on the national stage. However, there were negatives associated with this mindset also, and one of them was the distrust of women that it imbued, particularly in the sexual realm:

Sex was portrayed as a disease which lurked deep within the recesses of women's bodies. Unless it was controlled, it would awaken the most grotesque animal passions. [...] The Church was presented as the only means through which women could be saved from themselves. Sex was a sickness that could never be cured. It could only be monitored and controlled by the priest. It was such a dreadful disease that the patient, like the modern patient under a doctor, could only be told about it in vague terms $s^{4}$.

There is quite an uncanny resemblance between the sentiments expressed in these lines and what one finds in McGahern's early fiction, especially in the unpublished novel to which we will now turn our attention. The female protagonist in this narrative, Kathleen Lynch, views sex with a sceptically distrustful eye, which causes severe frustration and emotional strain for Hugh Mahoney, her boyfriend and the person through whom the story is narrated. Religion is omnipresent and oppressive in "The End or the Beginning of Love". The only healthy relationship is between Mahoney and his dying mother and it too is problematic in its intensity. The opening scene is reminiscent of what will be subsequently described in The Leavetaking and Memoir: it finds Hugh in his mother's bedroom speaking about his vocation to the priesthood. To her son's plea not to leave him, she replies:

"But I'll be up in heaven praying for you. When you grow up, you'll say Mass for me and I'll watch over you so that you can come to no harm. One day we'll meet in Paradise and we will be with each other for all eternity" (p. 15).

This is familiar terrain for McGahern readers. Hugh Mahoney feels guilty about the broken promise made to his sick mother that he would become a priest and pray for her eternal happiness. As happens with a number of McGahern's characters, and as was the case for the author himself, the priestly vocation

4. Tom Inglis, Moral Monopoly: The Catholic Church in Modern Irish Society, Dublin: Gill and Macmillan, 1987, p. 150. In Memoir, McGahern makes a similar point to Inglis': "At this time, because of the power of the Church and the Church's teaching, many married without any sexual knowledge or knowledge of the person they were marrying. The men married for sex. There was no other way to have it. The result was the arrival of a large number of children in rapid succession. [...] The ideal of the society was the celibate priest. The single state was thus elevated. The love of God was greater than the love of man or woman; the sexual was seen as sin-infected and unclean" (Memoir, p. 51-52). 
was sacrificed to the urgings of the flesh, to the desire to marry and live within a normal family context, with a wife and children. After his mother's death, Hugh realised that the spiritual commitment required to become a priest, the renouncement of sexual gratification in order to give everything to God, was too high a price to pay. His plight is not helped by his father's increasingly erratic and violent behaviour. The widower, reduced once more to the celibate state, takes out his frustrations on the children. One incident, narrated through the eyes of his son, reveals Mahoney senior's excitement when beating his daughter, Maura: "Even in the dim light he saw by his father's trousers that he was sexually aroused. Mahoney's face was horrible with passion" (p. 143). The enclosed, conservative society in which the family lives means that there is no question of seeking help from the local authorities to tackle these unwelcome beatings. In McGahern's own home, the father regularly inflicted severe violence on his young children, whose screams could be plainly heard by the other policemen in the barracks where they lived; yet no one intervened. On one occasion, some of his colleagues told Sergeant McGahern that the beatings would have to stop, but he carried on regardless, knowing that what a man did in his own home was nobody else's business and that he would not be reported.

My decision to concentrate on "The End or the Beginning of Love" and the 1965 novel The Dark is predicated on the fact that these are the two works that most starkly portray excessive Catholic guilt in McGahern's oeuvre. As the work evolved, more of his characters managed to escape from the grip of a belief system that concentrated to an unwarranted degree on the idea of the body being the temple of the devil. Hugh Mahoney remains trapped in a volatile home environment, where the father's moods can never be predicted. Hence the children must always be vigilant not to incite his anger. The priesthood offers the chance of an escape from this world, but when Hugh goes to visit his cousin, Fr Gerald, who, in keeping with the behaviour of his namesake in The Dark, comes to Mahoney's room in the middle of the night and climbs into the bed beside him. He ends up showing the boy the scars on his stomach, which leaves Hugh feeling awkward and uneasy 5 .

Once his vocation to the priesthood has been cast aside, Hugh feels easier about pursuing a relationship with the trainee teacher, Kathleen Lynch. However, this liaison will also end badly. Whenever passion takes hold of the couple, they end up loathing each other afterwards: "There was little kindness or tenderness in the lust of their love" (p. 265). Kathleen is the more puritanical of the two. On one occasion, she interrupts their courting with the words: "You shouldn't kiss me

\footnotetext{
5. As this constitutes a more crucial illustration of warped sexuality in The Dark than in the unpublished novel, we will deal with it in more detail later on.
} 
like that. Iit's wrong. Iit's sinful. Iit's passionate kissing" (p. 242). There are times when Hugh is forced to agree with his girlfriend, especially when he reflects on death and the fate that awaits him at the Final Judgement. Although somewhat dubious about Catholic doctrine, especially as it pertains to sex, he knows that his mind has been affected by the teaching he received at school and in the home: "[...] he was by no means free of the religion of his childhood; he would never be fully free" (p. 252).

As long as he is with Kathleen, it is unlikely that he will be allowed to forget that the physical attraction they feel for one another is wrong. He knows that she is not indifferent to his caresses, but she always pulls back when she feels things are getting out of control. She even goes so far as to say that sex within marriage is sinful: "[...] there's something dirty and disgusting about sex, something", she shuddered with revulsion, "unclean" (p. 293). Victims of a culture that is highly wary of sex, Hugh and Kathleen are in a sense incapable of escaping from the Catholic instruction they have received. The following line sums up their dilemma: "They all seem to have inherited the idea of the horrible ugliness and sewer filth of sex" (p. 293). In the writing of his maturity, McGahern would not have used such explicit language. But at this point in his development, he was intent on bringing to the fore the crippling effect a repressive religious regime can have on people's sexuality. Something that is natural and beautiful, something that should be embraced and cherished, is turned into what Hugh and Kathleen end up viewing as "the sewer filth of sex".

In his study of sexuality, Catholicism and literature in twentieth-century Ireland, Michael Cronin makes the following observation in relation to McGahern and his contemporary, Edna O'Brien: "sexuality is still an expression of rebellion and refusal, but it tends to be powerfully associated in both McGahern and O'Brien with feelings of abjection, trauma, grief and loss". This is certainly true of the early writings of McGahern, that portray in a most graphic manner the traumatic and upsetting impact that their early forays into the sexual domain have on his characters. The following unpalatable description emanates from Hugh's rather troubled mind:

It had come up before his own mind: black blood splashed against his pale skin of the loins, the stench of rotting fish, blood matted in the hair that twisted like a pile of worms, the rough edges of a tapeworm moving in the blood it fed on [...] He passed his hand across his eyes in horror. Their minds were diseased, blasphemous against life, the horrible smell of decay before death from them (p. 293).

6. Michael G. Cronin, Impure Thoughts: Sexuality, Catholicism and Literature in twentieth-century Ireland, Manchester, Manchester University Press, 2012, p. 181. 
These lines convey the impression that sex is something harmful ("black blood splashed" against the skin), a type of cancer that sucks the life out of people ("tapeworm moving in the blood it fed on"), a menacing danger to those who fall prey to it ("stench of rotting fish", "horrible smell of decay before death"). It suggests the disturbed attitudes of Hugh and his girlfriend, who unsurprisingly break up at the end of the story. The description above brings to mind the risk pointed out by the French philosopher, Michel Foucault, who wrote in The History of Sexuality:

If sex is repressed, that is, condemned to prohibition, nonexistence and silence, then the mere fact that one is speaking about it has the appearance of a deliberate transgression. A person who holds forth in such a language places himself to a certain extent outside the reach of power; he upsets the established law; he somehow anticipates the coming freedom ${ }^{7}$.

I think the prohibition on speaking openly about sex is something that was common practice in Irish society until fairly recently. Also, the Foucauldian concept of "transgression" applies very well to the two early texts by McGahern that we are considering in this article. The author's decision not to submit "The End or the Beginning of Love" for publication was a sensible one in my view, as it lacks the stylistic control and restraint of his published work. That said, it does show his early preoccupations as a writer and links in well with what one encounters in his second novel. In fact, with the publication of The Dark in 1965, McGahern upset what Foucauld refers to as the "established law" and paid the price for this "transgression". His first novel, The Barracks, had received a warm reaction from the critics such as Kate O'Brien, who declared how impressed she was by the artistic achievement from a young, inexperienced writer: "It is difficult to find words exact enough to express my admiration for this subtle, closewoven, tender, true, poetic work ${ }^{8}$." The way the young novelist was able to get into the mind of his middle-aged heroine, Elizabeth Reegan, who is diagnosed with terminal cancer, was quite remarkable, in O'Brien's view'. He follows her path through a relatively short illness up until death and captures her turmoil at leaving behind a material world for which she had little regard when in the bloom of good health. Because of the unprecedented success of The Barracks, much was expected from the reading public when The Dark finally appeared (all McGahern's

7. Michael Foucault, The History of Sexuality: An Introduction, trans. Robert Hurley, London, Penguin books, 1990 , p. 6.

8. Kate O'Brien, review of The Barracks in University Review, Vol. III, No. 4, 1963, p. 59.

9. He clearly drew on the painful, and ultimately unsuccessful, struggle his own mother had with the disease, dying when her eldest son was just ten years of age. 
novels were published by Faber \& Faber), but, instead of praise, the second novel earned public opprobrium for its author.

Val Nolan's in-depth analysis of the controversy surrounding the banning of The Dark is an indispensable reference point when attempting to understand the prevailing moral climate that dominated the Ireland of the mid-1960s ${ }^{10}$. The Barracks led to McGahern being awarded the prestigious Macauley Fellowship in 1964. One of the terms attached to this award (worth $£ 1,000$ at the time, a considerable sum of money) was that the successful candidate had to spend some time abroad. On the strength of this, McGahern therefore decided to ask for a year's leave of absence from his position as a national school teacher in Clontarf to work on his second novel. The esteem in which he was held around this time is attested to by his also winning the AE Memorial Award. The publication of The Dark would change the smooth trajectory on which the writer was embarked. Nolan relates how in May 1965, 260 copies of the novel arrived in Dublin "addressed to Messrs. Eason" and were immediately seized by officers of Customs and Excise $^{11}$. This action ignited a public scandal that seriously impacted on the life and writing career of McGahern and would involve many of the leading lights of Irish society at the time such as Archbishop Charles McQuaid and Owen Sheehy Skeffington. The former is alleged to have demanded that McGahern be removed from his teaching position in Scoil Eoin Báiste, a course of action that prompted Skeffington to call into question how a system was allowed to develop whereby a teacher was appointed (and sometimes dismissed) by a clerical manager and yet paid by the state. His real bone of contention, however, was how a book like The Dark could have been banned in the first instance, even though the author had wandered into some rather dangerous territory:

The book itself is a sensitive, well-written, rather sad and poignant book, dealing with aspects of Irish life which officialdom prefers to pretend do not exist. Masturbation, homosexual tendencies, the sexual frustrations of many Irish men and women including some priests, are dealt with in a courageous and frank manner, but with a sobriety and seriousness of concern which are undeniable ${ }^{12}$.

This is an excellent assessment of what McGahern was trying to achieve in his novel; he sought to unveil a rather unattractive underbelly at the heart of Irish society which no one really wanted to consider. Boys and girls regularly

10. Val Nolan, "If it was just th'oul book...': A History of the McGahern Banning Controversy" in Irish Studies Review, Vol. 19, No. 3, August 2011, p. 261-279.

11. Nolan, p. 262.

12. Owen Sheehy Skeffington, "McGahern Affair" in Censorship: A Quarterly Report on Censorship of Ideas and the Arts, 2.2 (Spring 1966), p. 27-30, p. 27. 
engaged in masturbation; some were sexually active; homosexuality existed in Ireland and there were frustrated men and women all around the country. This is a presentation of the situation that not many people would disagree with today. But the problem for McGahern was that very few writers (Edna O'Brien being an obvious exception) were prepared to expose this hidden Ireland in as stark a manner as he chose to do in the 1960s. Writing in The Irish Times, Terence de Vere White noted that sex made the book "claustrophobic". He wondered if it was "all written to titillate or shock?", before concluding: "I am not sure. The story has the wholeness of artistic integrity. How true it is must be a question to which different experience will give different answers ${ }^{13}$." The degree to which the artist has the right, perhaps even the responsibility, to portray human experience as s/he sees it without fear or favour, is clearly complicated when one drifts into the area of sexuality. What characteristics must a text possess for it to be considered pornographic? The desire to "titillate", which is mentioned by de Vere White, is clearly a key component, but it is very doubtful that such a desire inspired McGahern's writing in The Dark. Some days later, Sean Collins, writing once more about the banning in The Irish Times, felt that it was "a clear indication of the narrow, puritanical, and boorish mentality which still prevails in bureaucratic circles", and recommended that "our small, childish little parochial traits should have given way to a more mature and enlightened way of thinking ${ }^{14}$ ". When one considers the titles of some of the other 16 books that were banned at the same time as The Dark, such as Satin Legs and Stilettos, Fifty Dollars a Night and Give Me This Woman, it can be seen that McGahern was keeping strange company indeed, that is, if the salacious titles are anything to go by ${ }^{15}$. While he declined to become involved in the debate at the time, feeling that the artist's role was not to be a public figure but to produce good art, he did comment on the incident in many subsequent interviews, such as the one he did with Julia Carlson in which he argued that the banning was all about Ireland's attitude to sexuality. The fact that it was a time when the young state was insecure as to what direction it wanted to go meant that nobody really knew what to be Irish was: "There was this slogan and fanaticism and a lot of emotion, but there wasn't any clear idea except what you were against: you were against sexuality; you were against the English ${ }^{16}$." To McGahern's way of thinking, defining yourself by what you were against

13. "Five to One", The Irish Times, 8 May, 1965, p. 8.

14. Cited by Nolan, p. 263-264.

15. Nolan, p. 265. Nolan also quotes an editorial from the Irish Independent which, in his view, "attempted to play both sides of the fence by painting The Dark as not just undeserving of the ban, but undeserving of being read". 16. Julia Carlson (ed.), Banned In Ireland: Censorship and the Irish Writer, Athens, Georgia, University of Georgia Press, 1990, p. 63. 
was not a particularly healthy thing, especially when one of the things you were against was something as natural and sacred as sexuality.

Before beginning a discussion of the novel itself, I think it is worthwhile to consider briefly the correspondence between McGahern and a writer for whom he had great admiration, Michael McLaverty, around the time of the banning. McLaverty was known to be a devout Catholic and so how he reacted to his novel was a sort of litmus test for McGahern. The Belfast writer declared himself "greatly impressed by its painful sincerity and its pared-to-the-bone style" and continued: "The book rings with truth at every turn and it must have been a heartbreaking and exhausting book to write ${ }^{17}$." McLaverty did admit that he "recoiled" somewhat from a few pages in which a priest's thoughts were described, but his overall reaction was positive. That he recognised how difficult it must have been for McGahern to write the book shows his appreciation of the bravery it took for the emerging writer to tackle issues that were taboo at the time. The "truth" that McLaverty detects in the narrative is perhaps the most insightful part of his reading. Because the authenticity he brings to bear on his narrative is what gives The Dark its special resonance and is also what possibly led to its banning: McGahern cut too close to the bone and readers did not know how to react.

The Dark opens with a middle-aged widower, Mahoney, administering a simulated beating to his son, whom he has forced to undress and go into his sisters' bedroom. As the boy bends naked over a chair, Mahoney senior brings the strap down on the leather seat beside him. The sexual overtones are obvious: "He didn't lift a hand, as if the stripping compelled by his will alone gave him pleasure ${ }^{18}$." He issues orders in an imperious manner: "Move and I'll cut that arse off you. I'm only giving you a taste of what you're going to get" (p. 9). When it's all over, the leather strap resembles a limp penis after ejaculation and Mahoney's excitement is obvious: " $[\mathrm{H}]$ is face still red and heated, the leather hanging dead in his hand" (p. 10). The tenor of the narrative is set from the outset: "This is a classic dramatisation of patriarchal dominance being asserted through violence, a violence that has a definite sexual tenor. The boy is given a public humiliation, his sisters forced to observe him as he loses control and urinates on the chair: 'something in him snapped [...] He'd never imagined horror such as this, waiting naked for the leather to come down on his flesh, would it ever come, it was impossible and yet nothing could be much worse than this waiting" (p. 9). Broken and humiliated, the child runs away to the sanctuary of the lavatory at the end of the garden. Commenting on this scene, Kelly Jayne Steenholdt McGovern notes:

17. John Killen ed. Dear Mr McLaverty: The Literary Correspondence of John McGahern and Michael McLaverty 1959-1980, Belfast, The Linen Hall Library, 2006, p. 39.

18. John McGahern, The Dark, London, Faber \& Faber, 1965, p. 8. All subsequent references will be to this text, with page numbers in brackets. 
The treatment leaves the son irrevocably tainted by his leaking body; subsequently, the son will remain broken and impure, unable to even feel capable of controlling his body and fully redeeming himself ${ }^{19}$.

I had not made the link between Mahoney's "leaking body" and the subsequent orgies of self-abuse. In the opening scene, the young adolescent is made to feel as though he is not in control of his bodily functions, in the same way as he will discover later that his physical urges are too deep-seated for him to resist them. His promise to his mother that he would become a priest is rendered impossible by this perceived impurity. Using an advertisement for hair removal in the Irish Independent picturing a woman revealing the hair in her armpits as his stimulus, Mahoney pleasures himself and feels terrible guilt afterwards:

The pulsing dies away, a last gentle fluttering, and I can lie quiet. The day of the room returns, red shelves with the books and the black wooden crucifix, the torn piece of newspaper on the pillow. Everything is as dead as dirt. I'd committed five sins since morning (p. 31).

The crucifix is witness to this exhibition of self-abuse. The only hope of forgiveness is to go and confess his sins to a priest. Tom Inglis argues that "confession played a crucial role in sexualising the body", because it was the place "where the activities of the body were examined and suitable penances distributed ${ }^{20}$ " Young Mahoney regards confession as a type of mechanical means of clearing the slate and starting anew. The church pews are full of people who have come with the same intention as he has:

All waited for forgiveness, in the listless performance of habit and duty or torturing and turning over their sins and lives, time now to judge themselves and beg, on the final day there would be neither time nor choice (p. 39).

Top of the list of Mahoney's sins was, understandably, masturbation. The priest probes him about the "impure actions" and the number of times he gave in to temptation. The response, "More than two hundred times" (p. 41), is not commented on other than for the priest to say that Mahoney must fight that sin and pray for grace. Then he is given absolution and feels momentarily elated: "such relief had come to you, fear and darkness gone, never would you sin again" (p. 42). Steenholdt McGovern ${ }^{21}$ finds it interesting that the young protagonist

19. Kelly Jayne Steenholdt McGovern, “We have come of Age': Growing Bodies in the Twentieth Century Irish Novel”, unpublished PhD thesis, University of Maryland, 2012, p. 111. [http://drum.lib.umd.edu/bitstream/1903/12736/1/McGovern_umd_0117E_13142.pdf] Accessed 24 January, 2014.

20. Inglis, Moral Monopoly, p. 149.

21. "We have Come of Age", p. 145. 
never mentions in confession the abuse he (literally) suffers at his father's hands. The rhythmic rubbing of his stomach and genitalia by Mahoney senior, bringing both to orgasm, seems not to be considered sinful, however distasteful it may be to read or to endure. That it also causes the "seed to come", one of the criteria for unacceptable activity outlined by the priest, does not deem it worthy of disavowal. Somehow, abuse within the home, "the dirty rags of intimacy" (p. 19) between father and son, the "loathing" (p. 21) they inspire in the younger man, are exonerated, placed outside the list of peccadilloes that must be related to the priest in the confessional. When he imagines himself a priest and being privy to a woman's confession of illicit intercourse, Mahoney's sadomasochistic fantasies reveal themselves:

A whimper of grief in her voice, her dress would rustle, her face and young body close as inches to yours in the night. The same young thighs that had opened submissively wide to the man's rise the summer night by the river might open wide as that for you. She'd give you the fulfilment you craved. [...] Or would you burst out of the box and take her in madness? She'd said she'd been a virgin. She'd cried out with hurt in the river meadows but the man would not stop, he took her against her will. Would she cry too when the priest tore her clothes off and took her on the stone floor of the church? (p. 55).

Dermot McCarthy argues that Mahoney has a stronger desire for the warm bread of the flesh than the unleavened joy associated with the Host ${ }^{22}$. His vocation to the priesthood is constantly trumped by the sexual urgings that torment him. He believes he must be pure of mind and body if he is to aspire to the lofty vocation he has mapped out for himself. The trip he makes to stay with his cousin Fr. Gerald is a pretext for discussing what in fact he might do with his future. From the moment he arrives at the presbytery, he feels uneasy: his cousin has a boy of his own age keeping house for him, a choice that seems at best odd to Mahoney. Then the priest comes to his room in the middle of the night and proceeds to get into bed beside him: "[Y]ou stiffened when his arm went around your shoulder, was this to be another of the midnight horrors with your father" (p. 70). Fr. Gerald questions him about the doubts he harbours in relation to his vocation and then gets him to admit all in relation to his problems with masturbation. When then asked if he had to face the same type of problem when he was Mahoney's age, the priest blandly ignores the question. The silence in the room fills the boy with resentment: " $[\mathrm{H}] \mathrm{e}$ had broken down your life to the dirt, he'd reduced you to that, and no flesh was superior to other flesh [...] he was above

22. Dermot McCarthy, John McGahern and the Art of Memory, Oxford, Peter Lang, 2010, p. 92. 
that, you were impertinent to ask" (p. 74). The way this scene mirrors the nights when he has to endure his father's improper sexual advances, and the fact that in this instance the perpetrator is a priest, leads to bitter disillusionment. Dermot McCarthy offers the following assessment of this crucial episode in the novel:

The boy's fascination with the figure of the priest as a man like any other but with a supernatural power to absolve guilt is crucial for understanding his reaction to what he judges to be Father Gerald's failure to respond appropriately to his "confession"23.

Whereas the abuse in this instance is psychological rather than physical, it is nevertheless damaging to the self-esteem. Steenholdt McGovern raises an interesting question when she notes that there is an admission that "Young Mahoney might take a reluctant, vague and conditional pleasure ${ }^{24 "}$ in the abuse inflicted on him by his father. If that is the case, could there be a tinge of disappointment in his reaction to Fr. Gerald's failure to follow through on what in some ways would appear to be his seduction of the boy? After he leaves the bedroom, Mahoney masturbates for the first time in three weeks and on this occasion there is no need of any external stimulus such as "edge of nylon nor pink nipple in your teeth" (p. 76). He feels "restless and hot" (p. 75) and can find no release for his frustration other than the customary pumping of semen into his sock. To a certain extent, the masturbatory act may be directed against Fr. Gerald's leaving before anything sexual occurs between them. Whatever the reason, the next day he resolves to give up on the idea of becoming a priest and at the same time gains some sort of stature by releasing his sister Joan from the lascivious attentions of her employer, Mr. Ryan, who runs a drapery shop in Fr. Gerald's parish.

The episode with Ryan reveals something intriguing about the mindset of Mahoney. When asked by Ryan if he finds the sights of his daughters running around the garden in green swimsuits "tempting" (p. 92), Mahoney is angered by what he regards as a slight on him and his family. He wonders: "Why couldn't Ryan climb on his wife in the deck-chair, that's what he had married her for, or couldn't he tear off the swimsuits and straddle the pampered daughters or be whipped naked down the streets" (p. 93). This rather unwholesome view of marriage and the family causes Steenholdt McGovern to remark: "Young Mahoney does not here object to the sexual abuse of young women by patriarchal authorities in general, he objects to the external threat Ryan poses to the Mahoney family cell and expresses the belief that Ryan's sexual advances should be contained within the Ryan family cell ${ }^{25}$." This goes some way towards explaining why

23. McCarthy, The Art of Memory, p. 95.

24. Steenholdt McGovern, p. 134.

25. Ibid., p. 123. 
Mahoney does not confess what transpires between himself and his father in confession. Patriarchal abuse, provided that it is practised within the family, is seen as being in some way justified. Marriage and parenthood, both states cherished by the Catholic Church, confer certain rights on men like Ryan, particularly access to intercourse on demand: "that's what he'd married her (his wife) for".

There is a lot more that could be said about Catholic guilt in the early work of McGahern, but I trust that this article serves at least as an elucidation of the courageous and prophetic nature of this writer's approach to the problematic co-existence of Catholicism and sexuality in the Ireland of the mid-twentieth century. It was far from easy to explore the minefield that was sexual abuse in the home, implied clerical sex abuse, masturbation, sadomasochism, and the other taboo subjects broached by McGahern in the 1960s. He made people uncomfortable by daring to raise what was at the time unmentionable. With the aid of hindsight, his testimony has been vindicated, his words proven to be true. Families then, as now, are far from perfect; young men still "dream of the ecstasy of destruction on a woman's mouth ${ }^{26 "}$; priests have not always lived up to their lofty calling; people are imperfect vessels. Catholic guilt is no longer accepted to the same extent as a means of suppressing sexuality, and that is a good thing. But the increased sexualisation of young children, the rush to engage in sexual encounters devoid of love and commitment, the exploitation of both men and women by the sex trade, none of this indicates that current attitudes to sex are necessarily any healthier than what was portrayed by McGahern. Shortly after his death in 2006, Fintan O'Toole wrote the following comments about the issues raised by The Dark in particular:

By accurately describing the human interiors of Ireland, McGahern helped to alter Ireland's sense of reality. The starkest example of this is the issue of child sex abuse. When it hit the headlines in the 1990s, it was spoken of as a stunning and awful revelation, a secret that hardly anyone knew. Yet it is there in black and white in The Dark, thirty years before ${ }^{27}$.

McGahern did not see himself as a journalist, a person who forensically examines facts and offers opinions. His role was to create fictions that, if well written, would have the force of lived experience. This is certainly true of his early fiction's grappling with Catholic guilt, which resonates on a moral, theological, sociological and existential level and reveals undoubted truths about the Ireland of his youth and early childhood, a time when the spectre of the Catholic Church loomed large.

26. The Dark, p. 84.

27. Fintan O'Toole, "Picking the Lock of Family Secrets", The Irish Times, 1 April, 2006. 